\title{
Surveillance of antibiotic resistance in Streptococcus spp in China-CHINET project 2007 and 2009
}

\author{
W Chuanqing ${ }^{*}$, CHINET project \\ From International Conference on Prevention \& Infection Control (ICPIC 2011) \\ Geneva, Switzerland. 29 June - 2 July 2011
}

\section{Introduction / objectives}

CHINET program, which started at 2005, is monitors bacterial antibiotic resistance in 12 China medical centers in 2007 and 14 China medical centers in 2009

\section{Methods}

The susceptibility testing was carried out by unified protocol of Kirby-Bauer method (KB) were Streptococcus pneumonia (1699), $\beta$-hemolytic streptococci(1428) including GAS (756), GBS (451), GCS (34), GGS (140), and GFS (31) none classified (16), and Viridans streptococc group excluded S. pneumonia isolated from sterile parts (280). The susceptibility testing was assayed by Penicillin E-test were S. pneumonia and Viridans streptococcus. Results were analyzed according to CLSI2007 and 2009 criteria

\section{Results}

Penicillin non-susceptible strains (PISP+PRSP) isolated from no bacterial meningitis patients in children aged $<5$ year old group was $24.9 \%$, and Erythromycin resistance was $96.9 \%$, which were higher than that in $\geq 5$ year old group $(16.3 \%, 87.8 \%)$ separately . Erythromycin and Penicillin resistance were $88.7 \%, 0 \%$ in GAS, $52.3 \%$ and $2.6 \%$ in GBS, $61.8 \%$ and $6.7 \%$ in GCS, $58.1 \%$ and $0 \%$ in GFS, $57.0 \%$ and $0.7 \%$ in GGS, $66.7 \%$ and $21.3 \%$ in Viridans Streptococci group. All isolates were highly sensitivity to Levofloxacin, Vancomycin, Linezolid, Moxifloxacin and Meropenem

\section{Conclusion}

In conclusion, the resistant of S. pneumonia to penicillin is different between different age group. The resistant rates of streptococcus spp to erythromycin remain high in mainland China.

Nosocomial Infection Control, Children's Hospital of Fudan University, Shanghai, China

\section{Disclosure of interest}

None declared.

Published: 29 June 2011

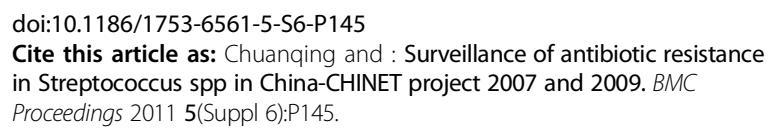

Submit your next manuscript to BioMed Central and take full advantage of:

- Convenient online submission

- Thorough peer review

- No space constraints or color figure charges

- Immediate publication on acceptance

- Inclusion in PubMed, CAS, Scopus and Google Scholar

- Research which is freely available for redistribution

Submit your manuscript at www.biomedcentral.com/submit

\section{( Biomed Central}

